\title{
Research of characteristics of environmental energy carriers by simulation of operating load in laboratory conditions
}

\author{
Romana Janouskova ${ }^{1, *}$, Jerzy Kaszkowiak ${ }^{2}$, Marek Halenar ${ }^{3}$, Martin Zachar $^{4}$, and Jozef \\ Nosian $^{1}$ \\ ${ }^{1}$ Slovak University of Agriculture in Nitra, Faculty of Engineering, Department of Transport and \\ Handling, Tr. A. Hlinku 2, 94976 Nitra, Slovak Republic \\ ${ }^{2}$ UTP University of Science and Technology in Bydgoszcz, Al. prof. S. Kaliskiego 7, 85-796 \\ Bydgoszcz, Poland \\ ${ }^{3}$ ARRIVA Slovakia a.s., Sturova 72, 94901 Nitra, Slovak Republic \\ ${ }^{4}$ University of Defence Brno, Faculty of Military Technology, Department of Combat and Special \\ Vehicles, Kounicova 65, 66210 Brno, Czech Republic
}

\begin{abstract}
The focus of this sceintific article is a laboratory research on the qualities of environmental energy carriers by simulating the operational load, focusing on changes of physico-chemical qualities of ecological hydraulic and transmission fluid used in agricultural tractors. In laboratory setting by using a simulator, it was possible to simulate different operational load and also track changes in qualities of hydraulic fluid by changing the flow in precise intervals. The hydraulic-transmission fluid used in the laboratory setting was the MOL Farm NH Ultra.
\end{abstract}

\section{Introduction}

Ecological fluids used in mobile energy products operating in an environmentally sensitive environment are subject to high requirements that manufacturers have to take into account during their development in order to improve their quality while reducing the burden on the environment $[1,2,3]$. This is a natural consequence of efforts to increase the efficiency of production processes primarily due to a reduction in production cost, reduction in energy consumption with emphasis on reducing environmental impacts caused by production itself, but also other dependent aspects [4]. A comprehensive analysis of the effect of biological fluids and mixtures thereof has already been dealt with author [5]. The change in the physico-chemical properties of the transmission-hydraulic fluid is an important indicator of the technical condition of the hydraulic pump and has a fundamental influence on the operation of individual elements of the hydraulic circuit. The oil level is evaluated according to either pre-scheduled intervals or continuously $[6,7,8]$. Proper technical diagnosis is provided high security and reliability with a view to extended maintenance cycles and limiting consequential damages. Objective technical status should be determined without dismantling and disruption [9]. It is appropriate to simulate the operational load in laboratory conditions for accelerated tests of ecological energy carriers. This also optimizes the laboratory test time and the possibility of multiple repetitions without the influence of the external environment which cannot be achieved in operational conditions $[10,11,2]$. After the end of operational load of ecological liquids, we analyze their physico-chemical properties and influence of used working fluid on the change of flow properties of the hydraulic pump.

\footnotetext{
*Corresponding author: xjanouskova@uniag.sk
} 


\section{Material and methods}

A laboratory test facility which allows laboratory tests to be performed based on signals recorded during field tests was designed in order to simulate the operational load of the gear pump used in the tractor's hydraulic system when applying the tested ecological-hydraulic fluid [3]. Experimental set of pressure measurement with numerical simulation in engines under laboratory conditions shortens the time required for realization of operational measurements [12]. The basic prerequisite for proper functioning and effective care of hydraulic fluids is a suitably chosen methodology for testing fluids with monitoring of the level of contamination of working fluid $[7,13,1]$. The research was focused on testing the ecological hydraulic transmission fluid after working 500 hours on the basis of standardized conditions according to the Vickers test.

Table 1. Basic technical data of universal biodegradable fluid.

\begin{tabular}{|c|c|c|}
\hline Parameter & Unit & Value \\
\hline Kinematic viscosity at $40^{\circ} \mathrm{C}$ & $\mathrm{mm}^{2} / \mathrm{s}$ & 67,5 \\
\hline Kinematic viscosity at $100{ }^{\circ} \mathrm{C}$ & $\mathrm{mm}^{2} / \mathrm{s}$ & 18,2 \\
\hline Density at $15{ }^{\circ} \mathrm{C}$ & $\mathrm{kg} / \mathrm{m}$ & 931 \\
\hline Flash point & ${ }^{\circ} \mathrm{C}$ & 212 \\
\hline Pour point & ${ }^{\circ} \mathrm{C}$ & -48 \\
\hline
\end{tabular}

Table 2. Parameters of hydraulic pump OHD 17 (Katalóg zubových čerpadiel, 2013).

\begin{tabular}{|c|c|c|c|c|}
\hline \multicolumn{2}{|c|}{ Parameters } & Label & Unit & Value \\
\hline \multirow{2}{*}{ Actual geometric volume } & nominal & $\mathrm{V}_{\mathrm{g}}$ & $1 / \mathrm{min}$ & 1500 \\
\cline { 2 - 5 } Rotations & minimum & $\mathrm{n}_{\min }$ & $1 / \mathrm{min}$ & 350 \\
\cline { 2 - 5 } & maximum & $\mathrm{n}_{\max }$ & $1 / \mathrm{min}$ & 3200 \\
\hline \multirow{2}{*}{ Inlet pressure } & minimum & $\mathrm{p}_{1 \min }$ & $\mathrm{MPa}$ & $-0,03$ \\
\cline { 2 - 5 } & maximum & $\mathrm{p}_{1 \max }$ & $\mathrm{MPa}$ & 0,05 \\
\hline \multirow{2}{*}{ Outlet pressure } & max. permanent & $\mathrm{p}_{2 \mathrm{n}}$ & $\mathrm{MPa}$ & 29 \\
\cline { 2 - 5 } & maximum & $\mathrm{p}_{2 \max }$ & $\mathrm{MPa}$ & 31 \\
\cline { 2 - 5 } & peak & $\mathrm{p}_{3}$ & $\mathrm{MPa}$ & 32 \\
\hline
\end{tabular}




\begin{tabular}{|c|c|c|c|}
\hline Nominal input flow (min.) at $\mathrm{n}_{\mathrm{n}}$ and $\mathrm{p}_{2 \mathrm{n}}$ & $\mathrm{Q}_{\mathrm{n}}$ & $\mathrm{dm}^{3} / \mathrm{min}$ & 23,2 \\
\hline Maximum flow at $\mathrm{n}_{\max }$ and $\mathrm{p}_{2 \max }$ & $\mathrm{Q}_{\max }$ & $\mathrm{dm}^{3} / \min$ & 54,3 \\
\hline
\end{tabular}

The course of the laboratory test was based on the operational measurement of the hydraulic system of the agricultural wheeled tractor ZETOR FORTERA 114 41. We determine the procedure for evaluating the high-performance product line of the QHD 17 gear pumps with the Vickers test method. Test conditions defined by the Vickers test method are stated in Table 3. Tested work fluid is the ecological transmission-hydraulic oil MOL Farm NH Ultra which properties are from the manufacturer and are stated in Table 1.

Table 3. Test conditions according to the test method.

\begin{tabular}{|c|c|c|}
\hline Parameter & Unit & Value \\
\hline Rotations & $1 / \mathrm{min}$ & $2350-2400$ \\
\hline Loading pressure & $\mathrm{MPa}$ & $20,5-21$ \\
\hline Inlet pressure & $\mathrm{MPa}$ & $\max .0,15$ \\
\hline Outlet temperature & ${ }^{\circ} \mathrm{C}$ & $90-96$ \\
\hline
\end{tabular}

Table 4. Basic properties of the tested hydraulic fluid Mol Farm NH Ultra.

\begin{tabular}{|c|c|c|}
\hline Characteristic & Unit & Value \\
\hline Density at $15^{\circ} \mathrm{C}$ & $\mathrm{kg} / \mathrm{m}$ & 875 \\
\hline Kinematic viscosity at $40^{\circ} \mathrm{C}$ & $\mathrm{mm}^{2} / \mathrm{s}$ & 64,2 \\
\hline Kinematic viscosity at $100{ }^{\circ} \mathrm{C}$ & $\mathrm{mm}^{2} / \mathrm{s}$ & 10,9 \\
\hline Viscosity index & - & 162 \\
\hline Pour point & ${ }^{\circ} \mathrm{C}$ & -36 \\
\hline Flash point in open container & ${ }^{\circ} \mathrm{C}$ & 210 \\
\hline
\end{tabular}

The Vickers test is determined to be 50 hours without interruption, while the standard determines the different heating phases and the flow rate measurements are taken in 5-hour intervals. In our laboratory conditions, we have adjusted this test to 100 hours by simulating a pressure load that will be intermittent after 10 hours and the flow characteristics of the pump will be measured and recorded in 25-hour intervals. The change in fluid flow for gear pumps is determined by the Vickers test method only by a maximum of $3,75 \%$. Methodological procedure for sampling of hydraulic fluid tested is governed by the standard STN 656207 (Hydraulic oils and liquids. Sampling for determination of mechanical impurities content.). In order to assess the suitability of the hydraulic fluid tested in the hydraulic circuits of agricultural, forestry and handling equipment, it is 
necessary to know the input parameters of the system in which the hydraulic fluid will be tested, i.e. the technical parameters of the pump (Table 2).

\section{Results}

\subsection{Flow characteristics of the pump overtime}

In Fig. 1 is a graphical comparison of the flow rate variation of the hydraulic pump after 500 hours of operating load simulation under laboratory conditions where the flow rate variation is depicted depending on the speed range from $500 \mathrm{rpm}$ to $2750 \mathrm{rpm}$.

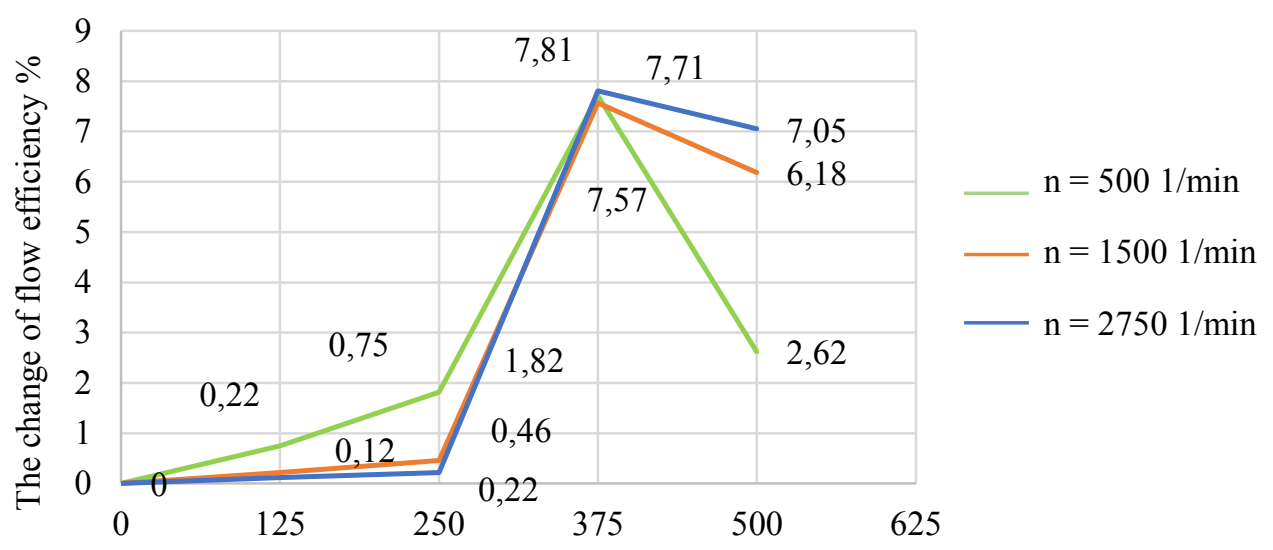

Hours worked

Fig. 1. Comparison of the change in flow efficiency from based on hours worked.

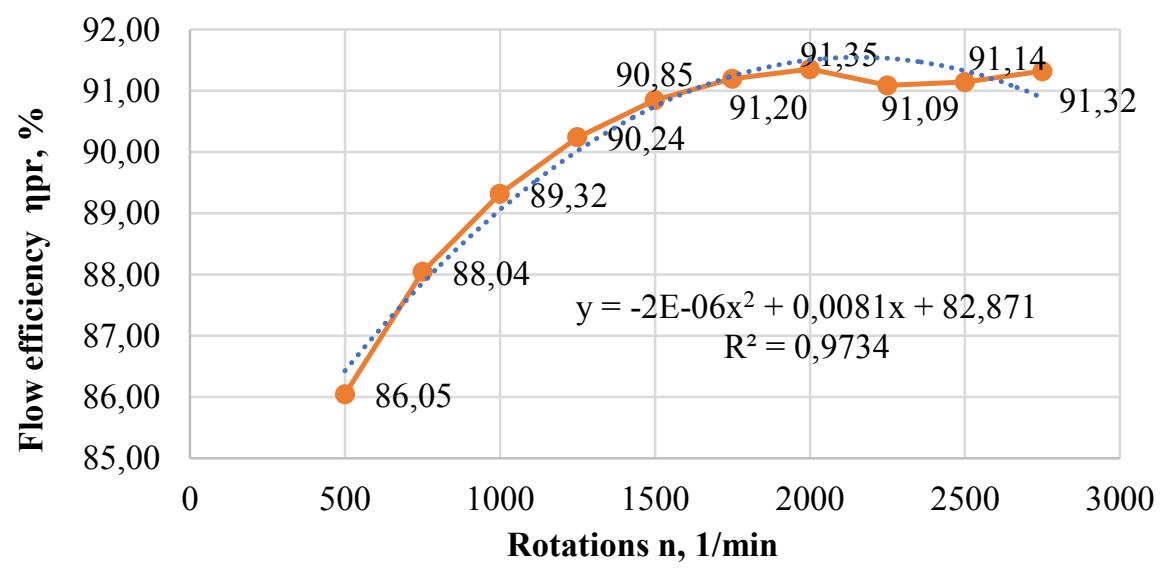

Fig. 2. Flow efficiency of the hydraulic pump at 0 hours - Vickers test method.

Fig. 2 shows the flow efficiency of the pump after 500 hours worked, depending on the minimum speed, from $500 \mathrm{rpm}$ to $2750 \mathrm{rpm}$. Flow efficiency at $500 \mathrm{rpm}$ reached $86,05 \%$ and at $2750 \mathrm{rpm}$ reached $91,32 \%$. The greatest increase in flow efficiency as a function of speed is between $500 \mathrm{rpm}$ and $1500 \mathrm{rpm}(4,8 \%)$, after exceeding the rated speed of 1500 $\mathrm{rpm}$ to the value of $2750 \mathrm{rpm}$ the flow efficiency increased $(0,47 \%)$. 


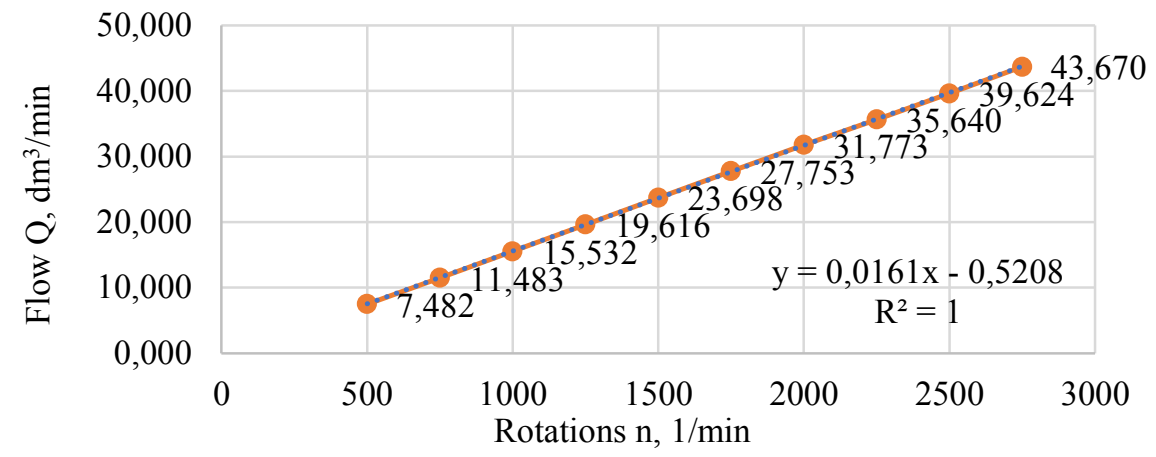

Fig. 3. Flow characteristic of the hydraulic pump at the start of the test Vickers.

Fig. 3 shows the flow characteristic of the pump after 500 hours worked, where we started the measurement with the Vickers test method depending on the minimum speed from $500 \mathrm{rpm}$ to $2750 \mathrm{rpm}$. The flow rate at $500 \mathrm{rpm}$ reached $7,48 \mathrm{dm}^{3} / \mathrm{min}$ and at 2750 $\mathrm{rpm}$ it reached $43,67 \mathrm{dm}^{3} / \mathrm{min}$. The increase in the flow characteristic has a linear course as a function of speed, with a value of $36,19 \mathrm{dm} 3 / \mathrm{min}$ between $500 \mathrm{rpm}$ and $2750 \mathrm{rpm}$. Table 5 shows the flow characteristics of the pump after 25 hours worked in accordance with the Vickers test method in dependence on a minimum speed of $500 \mathrm{rpm}$ to $2750 \mathrm{rpm}$.

Table 5. Basic statistical evaluation of the flow characteristics of the hydraulic pump after 25 hours test Vickers.

\begin{tabular}{|c|c|c|c|c|c|c|c|c|c|}
\hline $\begin{array}{c}\text { Flow Q } \\
\text { at }\end{array}$ & Average & Median & Modus & Min. value & Max. value & Spread & $\begin{array}{c}\text { Stand. } \\
\text { deviation }\end{array}$ & Var. coef. & $\begin{array}{c}\text { Flow } \\
\text { efficiency }\end{array}$ \\
\hline $\begin{array}{c}n \\
1 / \min \end{array}$ & $\bar{x}$ & $\mathrm{Me}$ & Mo & $\mathrm{x}_{\min }$ & $\mathrm{x}_{\max }$ & $\sigma^{2}$ & $\sigma$ & $V_{k}$ & $\%$ \\
\hline 500 & 8,030 & 8,040 & 8,020 & 7,930 & 8,160 & 0,001 & 0,038 & 0,471 & 92,35 \\
\hline 750 & 12,488 & 12,490 & 12,530 & 12,270 & 12,670 & 0,006 & 0,076 & 0,609 & 95,75 \\
\hline 1000 & 16,883 & 16,880 & 16,880 & 16,750 & 17,010 & 0,003 & 0,056 & 0,331 & 97,08 \\
\hline 1250 & 21,316 & 21,310 & 21,290 & 21,170 & 21,450 & 0,003 & 0,055 & 0,257 & 98,06 \\
\hline 1500 & 25,776 & 25,770 & 25,770 & 25,630 & 25,940 & 0,004 & 0,064 & 0,248 & 98,82 \\
\hline 1750 & 30,197 & 30,180 & 30,140 & 30,060 & 30,370 & 0,005 & 0,073 & 0,242 & 99,22 \\
\hline 2000 & 34,566 & 34,570 & 34,650 & 34,390 & 34,720 & 0,006 & 0,078 & 0,226 & 99,38 \\
\hline 2250 & 38,844 & 38,850 & 38,850 & 38,470 & 39,110 & 0,021 & 0,143 & 0,369 & 99,28 \\
\hline 2500 & 43,095 & 43,110 & 42,920 & 42,800 & 43,430 & 0,026 & 0,161 & 0,373 & 99,12 \\
\hline 2750 & 47,366 & 47,360 & 47,310 & 47,050 & 47,670 & 0,020 & 0,143 & 0,302 & 99,05 \\
\hline
\end{tabular}




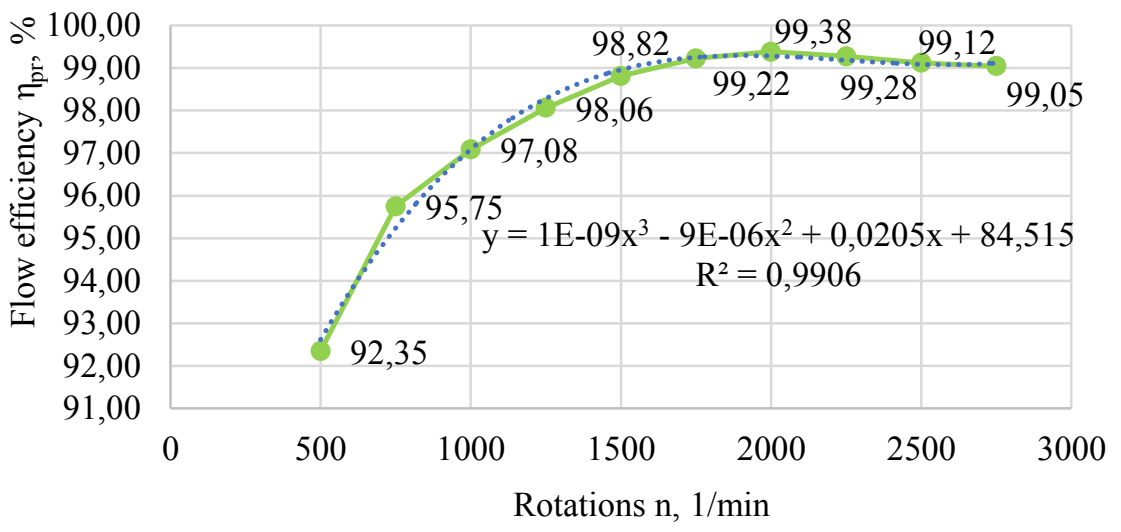

Fig. 4. Flow efficiency of the hydraulic pump after 25 hours - test Vickers.

Table 4 shows the flow efficiency of hydraulic pump after 25 hours, between $500 \mathrm{rpm}$ to $2750 \mathrm{rpm}$. Flow efficiency at $500 \mathrm{rpm}$ was $92,35 \%$ and at $2750 \mathrm{rpm}$ the flow efficiency was $99,05 \%$. The biggest increase in flow efficiency based on rated speed was between 500 $\mathrm{rpm}$ and $1500 \mathrm{rpm}$, at $6,47 \%$, after exceeding the rated speed of $1500 \mathrm{rpm}$ to the value of speed $2750 \mathrm{rpm}$, the flow efficiency increased $(0,23 \%)$.

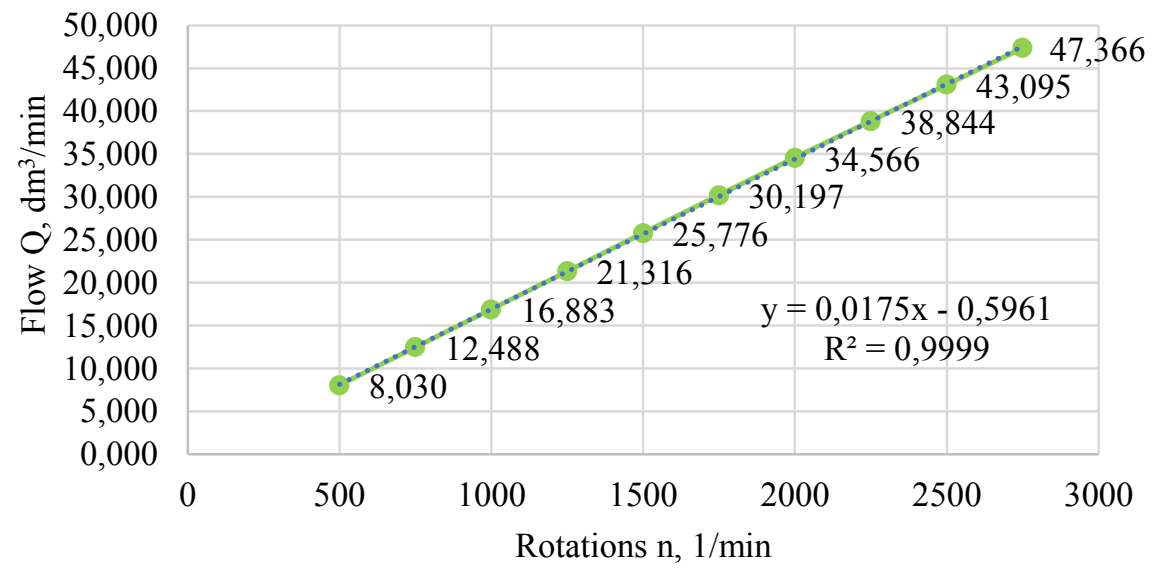

Fig. 5. Flow efficiency of the hydraulic pump after 25 hours - test Vickers.

Table 5 shows the flow rate characteristic of the pump after 25 hours depending on the minimum speed of $500 \mathrm{rpm}$ to $2750 \mathrm{rpm}$. The flow rate at $500 \mathrm{rpm}$ reached $8,03 \mathrm{dm}^{3} / \mathrm{min}$ and at $2750 \mathrm{rpm}$ it reached $47,37 \mathrm{dm}^{3} / \mathrm{min}$. The increase in the flow characteristic has a linear course as a function of speed, with a value of $39,34 \mathrm{dm}^{3} / \mathrm{min}$ between $500 \mathrm{rpm}$ and $2750 \mathrm{rpm}$. Comparing the flow efficiency of the pump after working for 25 hours, according to the Vickers test method, the flow rate shows an increase in flow efficiency of $8,77 \%$ at a rated speed of $1500 \mathrm{rpm}$. The increase in flow efficiency is attributed to changes in the physico-chemical properties of the liquid and changes in laboratory test conditions. The working temperature of the monitored liquid changes from $60{ }^{\circ} \mathrm{C}$ during a 500 -hour test to $90-96{ }^{\circ} \mathrm{C}$, the operating load changes from the maximum pressure of $14,11 \mathrm{MPa}$ during a 500-hour test to a value of $21 \mathrm{MPa}$ during a 100-hour test. The Vickers test has changed the kinematic viscosity, which is attributed to an increase in flow efficiency. 


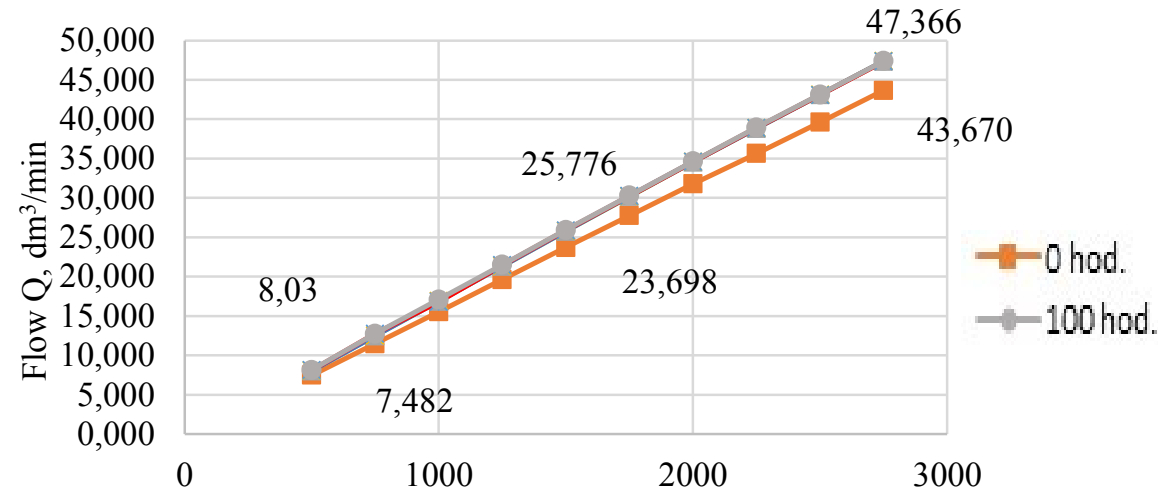

Rotations $\mathrm{n}, 1 / \mathrm{min}$

Fig. 6. Comparing the flow characteristics of pump - test Vickers.

Fig. 6 shows a graphical comparison of the flow characteristics of the hydraulic pump after each hour of working in accordance with the Vickers test conditions versus a minimum speed of $500 \mathrm{rpm}$ to $2750 \mathrm{rpm}$. When comparing the flow rate of the pump after working for 25 hours, according to the Vickers test method, the flow chart shows an increase in flow rate of $8,77 \%$ at a rated speed of $1500 \mathrm{rpm}$. Given the established methodology and the Vickers test method for gear pumps, a flow rate variation of 3,75\% is permissible, suggesting that the biodegradable universal fluid does not comply with the Vickers test, after the first 25 hours of laboratory testing under standardized conditions Vickers test.

\section{Conclusion}

According to [15] and [16], the hydrostatic pressure transfer system and the use of the hydrodynamic principle requires a perfect medium, therefore the hydraulic fluid must meet all the conditions encountered in the operation of hydraulic systems. Determination of the state and transfer of thermal and oxidative degradation of the oil is the most important criterion for oil life [5]. While using the biodegradable universal fluid, the flow rate of the hydrogenator after 500 hours worked reached $7,48 \mathrm{dm}^{3} / \mathrm{min}$ at $500 \mathrm{rpm}$ and at $2750 \mathrm{rpm}$ it reached $43,67 \mathrm{dm}^{3} / \mathrm{min}$, an increase of $36,19 \mathrm{dm}^{3} / \mathrm{min}$. After a subsequent 100 -hour Vickers test, the hydraulic pump flow rate at $500 \mathrm{rpm}$ reached $8,14 \mathrm{dm}^{3} / \mathrm{min}$ and at $2750 \mathrm{rpm}$ it reached $47,40 \mathrm{dm}^{3} / \mathrm{min}$, an increase of $39,25 \mathrm{dm}^{3} / \mathrm{min}$. The flow characteristics were almost linear over the entire duration of the laboratory test. The stated flow characteristics of the hydraulic pump correspond with the measured result according to [17], during the verifying measurement of a proposed laboratory test facility for testing hydraulic pumps and transmission-hydraulic fluids. When comparing the flow characteristic of the pump after working for 0 to 25 hours, according to the Vickers test method, an increase in flow characteristic of $8,77 \%$ at a rated speed of $1500 \mathrm{rpm}$ was observed. In view of the established methodology and the evaluation of the Vickers test method for gear pumps, it is permissible to change the flow rate by $3,75 \%$, indicating that the biodegradable universal liquid does not comply with the Vickers test after the first 25 hours of laboratory testing conditions according to the Vickers test.

This work was supposed by project VEGA 1/0155/18, ,Applied research of the use ecological energy carriers in agriculture, forestry and transport technology." 
This work was supposed by project KEGA 028SPU-4/2019 „Practical utilization of design and testing knowledge of transmission systems of hydraulic mechanisms of mobile agriculture and forestry machinery."

This work was supposed by project APVV SK-PL-18-0041 „The development of scientific cooperation in the study of the effect of biofuels in road transport, including environmental impact."

\section{References}

1. J. Kosiba, Z. Tkáč, L'. Hujo, B. Stančík, I. Štulajter, RAE, 59, 27 (2013)

2. Z. Tkáč, Š. Čorňák, V. Cviklovič, J. Kosiba, J. Glos, J. Jablonický, R. Bernát, ATA, 20, 42 (2017)

3. L. Hujo, Š. Čorňák, Z. Tkáč, M. Jánošová, TAE, 183 (2019)

4. I. Kuric, I. Zajačko, M. Cisár, Adv. Sci. Technol. Res. J., 10, 59 (2016)

5. M. Puškár, A. Jahnátek, I. Kuric, J. Kádárová, M. Kopas, M. Šoltésová, Air Qual. Atmos. Health , 12, 855 (2019)

6. J. Jablonický, Z. Tkáč, R. Majdan, D. Uhrinová, L'. Hujo, V. Vozárová, Hodnotenie vlastnostni biopalív a biomazív (2012)

7. J. Tulík, L'. Hujo, J. Kosiba, J. Jablonický, M. Jánošová, RAE, 63, 1 (2017)

8. M. Kučera, Z. Aleš, Z. Ivandić, L. Hujo, JCEA, 14, 1592 (2013)

9. M. Košinár, I. Kuric, Adv. Sci. Technol., 6, 115 (2011)

10. M. Zastempowski, J. Agr. Eng. Res., 58, 188 (2013)

11. J. Kosiba, Š. Čorňák, J. Glos, J. Jablonický, V. Vozárová, A. Petrovič, J. Csillag, JAR, 14, 1626 (2016)

12. M. Puškár, T. Brestovič, N. Jasminská, Int. J. Veh. Des., 67, 63 (2015)

13. B. Kopiláková, J. Turza, L. Hujo, J. Kosiba, Tribology in Industry, 39, 129 (2017)

14. Š. Čorňák, ERDev, 2048 (2018)

15. L. Hujo, P. Kangalov, J. Kosiba, Laboratory test devices for evaluating the lifetime of tractor hydraulic components (2015)

16. M. Simikić, N. Dedović, L. Savin, M. Tomić, O. Ponjičan, Soil Till. Res., 141, 32 (2014)

17. L. Hujo, Z. Tkáč, J. Tulík, J. Kosiba, D. Uhrinová, M. Jánošová, RAE, 62, 24 (2016) 